\title{
Azara corrige a Garcilaso: sentimiento y razón
}

\author{
Ana Isabel Martín Puya \\ Universidad de Córdoba
}

CES.XVIII, núm. 25 (2015), págs. 129-160. 


\section{Resumen}

Ilustración y neoclasicismo hallan en el término «Razón» una de sus más firmes bases. La razón se convierte en norma y aspiración para buena parte de los intelectuales dieciochescos, haciéndose visible como ideal en obras de muy diversa índole. El sentimiento, por su parte, ha de ser pasado por el tamiz de la razón. En este trabajo se analiza la manifestación de ambos integrantes del habitual binomio en las Obras de Garcilaso de la Vega, ilustradas con notas (Madrid, Imprenta Real de la Gaceta, 1765) por José Nicolás de Azara, edición que recuperó para las prensas la obra del poeta toledano tras una larga ausencia de las mismas, presentándolo como modelo del «buen gusto» en base a una estética neoclásica promovida bajo el reinado de Carlos III.

\section{Palabras clave}

Razón, sentimiento, Garcilaso, Azara, lírica, Siglo de Oro, Ilustración, neoclasicismo.

\section{ABSTRAC}

Enlightenment and Neoclassicism find in the term «Reason» one of their firmest bases. Reason becomes norm and aim for a great number of the XVIIIth Century intellectuals, becoming visible as ideal in works of various kinds. Feelings, on the other hand, must be passed through the sieve of reason. In this work, I analyse how both elements of the binomial manifest themselves within Obras de Garcilaso de la Vega, ilustradas con notas (Madrid, Imprenta Real de la Gaceta, 1765) by José Nicolás de Azara, an edition which recovered for the printing presses the work of the poet from Toledo after a long absence from them, presenting it as a model of «buen gusto» according to a neoclassical aesthetics promoted under the reign of Carlos III.

KEYWORDS

Reason, feeling, Garcilaso, Azara, lyric, Golden Age, Enlightenment, Neoclassicism. Recibido: 1 de junio de 2015. Aceptado: 4 de septiembre de 2015. 
Garcilaso se hizo poeta estudiando la docta Antigüedad; las notas lo prueban, y este es el modelo que presento a mis paisanos.

AZARA

Las Obras de Garcilaso de la Vega, ilustradas con notas ${ }^{1}$ (1765), que devolvió a las prensas las poesías del toledano tras una ausencia de más de un siglo y que recuperó la tradición de los comentarios canonizadores del denominado «príncipe de la lírica castellana» ${ }^{2}$, inaugurada por Sánchez de las Brozas, parece haber pasado con más pena que gloria en el desarrollo de la historia y crítica literarias. Pese a que contó con reediciones a finales del XVIII y principios del XIX, y que el prólogo del propio Azara se mantuvo en las ediciones garcilasianas durante más de un siglo, su presencia en los estudios críticos se ha visto habitualmente reducida a breves menciones que simplifican o denigran su valor, tal vez por haber respondido la publicación a unos intereses bien distintos a los de los estudiosos, o bien por haberse desconocido o desvirtuado, con no poca frecuencia, no tanto el objetivo como la metodología empleada por el conocido ilustrado. Es evidente que la de José Nicolás de Azara, oficial de la Secretaría de Estado en el momento de la publicación, no es una edición crítica ni de un rigor filológico que desvele claves en la transmisión y configuración del texto en sus anteriores manifestaciones; tampoco era este el objetivo del oscense. A esto se le añade el hecho de que las notas de Azara sean esencialmente un compendio de las del Brocense, Herrera y, en menor medida, Tamayo. Sin embargo, es bien sabido que tanto la adopción de modelos como la elocuente selección de un corpus suponen de por sí una decisión esclarecedora de intereses e intencionalidad de quien los realiza; así como que no solo transmite lo que se dice, sino también los encarecidos silencios ${ }^{3}$. El intervencionismo de Azara en el texto de

\footnotetext{
1 Garcilaso de la VEGA, Obras de Garcilaso de la Vega, ilustradas con notas [ed. de José Nicolás de Azara], Madrid, Imprenta Real de la Gaceta, 1765. La paginación (en cuerpo de texto) remite siempre a esta edición.

2 Entre otros, por Diego de SaAvedra Fajardo, República literaria, 1670 [1655], pág. 42.

3 Aunque probablemente bastaría el hecho de que la edición de Azara recuperara la obra de uno de los indiscutibles abanderados del movimiento neoclásico para la imprenta tras una ausencia dilatada (de uno
} 
Garcilaso, la notación selecta que parafrasea fragmentos de los comentaristas anteriores e incluye escasos comentarios propios, así como el elocuente prólogo que antepone, sin firmar, a la edición, todo redunda en una misma finalidad: ofrecer a Garcilaso como modelo del ideal neoclásico (de escritura y de autor), propuesto para la regeneración de unas letras nacionales de buen gusto.

\section{La edición de Azara y su contexto}

A la altura de 1765 Garcilaso había sido propuesto ya como modelo ${ }^{4}$ (junto a otros autores) en aras de la recuperación del buen gusto, sintagma representativo de una concepción que sobrepasaba los límites de lo artístico y literario, frente a la degeneración estilística y de la lengua castellana que suponía el mal gusto, estrechamente identificado con la estética barroca ${ }^{5}$. La importancia de Garcilaso había sido tal que se había convertido en referente para el inicio del periodo de mayor esplendor de las letras (y las armas), el «siglo de oro», conceptualizado con un valor historiográfico en los Orígenes de la poesía castellana ${ }^{6}$. Cuando José Nicolás de Azara ${ }^{7}$, «miembro distinguido

de los autores de referencia propuestos como modelo por tratadistas como Luzán, en su Poética [1727], y Mayans, quien lo convierte en uno de los autores más citados en su Rhetórica [1754]), de ser «el puente que salva los versos del toledano para transmitirlos a los lectores del Romanticismo», de elegir a Garcilaso «entre los clásicos de nuestra literatura nacional» (Antonio GALLEGo Morell, Garcilaso de la Vega y sus comentaristas, Madrid, Gredos, 1972, págs. 71-72), para no poderle negar una valía digna de una mayor profundización en su germinación e influencia, en la edición de Azara se hace patente el intervencionismo del editor en pos de una adecuación del texto garcilasiano al ideal neoclásico defendido como modelo para la regeneración del buen gusto (vid. Ana Isabel Martín PuYa, Las «Obras de Garcilaso de la Vega, ilustradas con notas» (1765) por José Nicolás de Azara, Vigo, Editorial Academia del Hispanismo, en prensa).

4 Sobre la recepción de Garcilaso en el XVIII puede verse Ana Isabel MARTín PuYA, «La coronación de un príncipe para la poesía castellana: para la recepción de Garcilaso en el siglo XvIII» (Bulletin hispanique, en prensa). Algunos trabajos más generales y de gran interés sobre la recepción de la poesía áurea en el XVIII son: Inmaculada UrZainQui, «El Parnaso español en la historia literaria del siglo XVIII», Bulletin hispanique, 109, 2, (2007), págs. 643-684; María Teresa Bautista Malillos, «Poesías de los siglos XVI y XVII impresas en el siglo XVIII», Cuadernos bibliográficos, 48 (1988); Françoise ÉTIEnVRe, «Entre Mayans y Luzán: la necesidad de un Parnaso", Bulletin hispanique, 109, 2 (2007), págs. 685-708; José Lara Garrido y Belén Molina Huete, eds., Estudios sobre la recepción y el canon de la literatura española, Madrid, Visor, 2013.

5 Hasta ese momento, los elogios dirigidos al toledano habían versado sobre la dignificación del lenguaje castellano, su dulzura y elegancia, y la introducción (o la consolidación de su uso) de los metros italianos y géneros grecolatinos en nuestra literatura, principalmente.

6 Como ocurre de manera generalizada entre los neoclásicos, Velázquez se refiere bajo esta denominación principalmente al siglo Xvi en Luis José Velázquez, Orígenes de la poesía castellana, Málaga, Francisco Martínez de Aguilar, 1754, págs. 66-67.

7 En los últimos años han aparecido aportaciones de enorme relevancia para la profundización en la figura de Azara y en el papel que desempeñó en los campos político y cultural del siglo ilustrado europeo; en este sentido, vid. Gabriel Sánchez Espinosa, La biblioteca de José Nicolás de Azara, Madrid, Calcografía Nacional / Real Academia de Bellas Artes de San Fernando, 1997; José Nicolás de AzARA, Memorias del 
de la minoría ilustrada vinculada a Carlos $\mathrm{III}^{8}{ }^{8}$, da a las prensas la edición setecentista «por excelencia» ${ }^{9}$ de la obra garcilasiana, han transcurrido décadas desde la aparición de la Poética ${ }^{10}$ (1737), con la que Luzán había tratado de solventar la ausencia de una preceptiva que sentara las bases de una poesía «neoclásica», y Velázquez había inaugurado once años antes el camino para la historización sistemática de la literatura castellana, en una suerte de «protohistoria» literaria ${ }^{11}$. Mayans, por su parte, mantenía una intensa dedicación a su pretendida restauración de un humanismo clásico y renacentista en las letras españolas, que promoviera la vuelta de una cultura nacional basada en principios clásicos, donde priman la imitación ${ }^{12}$ y el lenguaje ${ }^{13}$ como aspec-

ilustrado aragonés José Nicolás de Azara, ed. de Gabriel Sánchez Espinosa, Zaragoza, Institución Fernando el Católico, 2000; José Nicolás de AzAra, Epistolario (1784-1804), ed. de María Dolores Gimeno Puyol, Madrid, Castalia, 2010; María Dolores Gimeno Puyol, Primera memoria de José Nicolás de Azara, Zaragoza, Institución Fernando el Católico, 2014. Sobre la labor editora de Azara y sus relaciones con el ideario ilustrado, vid. Gabriel SÁnchez Espinosa, «José Nicolás de Azara, lettore, bibliofilo ed editore neoclassico», en Paesaggi europei del Neoclassicismo, ed. de G. Cantarutti y S. Ferrari, Bologna, II Mulino, 2007, págs. 141-162; Gabriel SÁnchez Espinosa, «La obra del naturalista Guillermo Bowles y la política editorial del gobierno ilustrado», Dieciocho: Hispanic Enlightenment, 25:2 (2002), págs. 255-280; Gabriel SÁnchEz EspinosA, «José Nicolas de Azara, traductor: la Historia de la vida de Marco Tulio Cicerón de Conyers Middleton», en La traducción en España (1750-1830): lengua, literatura, cultura, coord. por Francisco Lafarga Maduell, 1999, págs. 285-296; Gabriel SÁnchez Espinosa, «La relación de las exequias de Carlos III en Roma y el nuevo gusto neoclásico», Goya: revista de arte, 282 (2001), págs. 169-177.

8 María Dolores Gimeno Puyol, «Actualidad de José Nicolás de Azara, un testigo excepcional del Siglo de las Luces», en Le XVIII siècle aujourd'hui. Présences, lectures et réécritures, París, Éditions Le Manuscrit, 2011, págs. 385-402, en pág. 385.

9 En tanto que gozó de fortuna y difusión en la época, como prueban las reediciones que se sucedieron en las imprentas de Sancha en 1786, 1788 y 1796 en distintos formatos. Ya en el xix, como ha señalado Simón DíAz (Bibliografía de la literatura hispánica, Madrid, Gredos, 1980), reaparecen en 5 ocasiones entre 1804 y 1821 (3 en Madrid, 1 en Barcelona y 1 en París).

10 Ignacio de LuZán, La Poética o Reglas de la poesía en general, y de sus principales especies, Zaragoza, Francisco Revilla, 1737.

11 Sobre Velázquez véase Jesús Alejandro Rodríguez AylLón, Un hito en el nacimiento de la historia de la literatura española: los «Orígenes de la poesía castellana»(1754) de Luis José Velázquez, Málaga, Fundación Unicaja, 2010.

12 En el XVIII «se cree que el renacimiento de las letras fue posible gracias al auténtico conocimiento de los clásicos. El reconocimiento de este hecho fundamental es una invitación a los poetas del presente a una renovación partiendo nuevamente de los clásicos griegos y latinos (neoclasicismo)» (Emilio Palacios FernánDEZ, «Los poetas de nuestro Siglo de Oro vistos desde el siglo XVIII», en II Simposio sobre el padre Feijoo y su siglo, vol. 2, Oviedo, Centro de Estudios del Siglo XviI, 1983, págs. 517-543).

13 Un elemento clave dentro del protagonismo que Mayans otorga a la lengua es su vinculación con la utilidad y la razón. Así, a las virtudes de facilitar el comercio y favorecer la gloria de la nación, se añade la concepción de que, con el conocimiento de la lengua, «los de la propia nación se hacen mucho más racionales, teniendo un medio fácil para aprender las artes y ciencias» (Gregorio MaYANS Y SiSCAR, Obras completas, I, edición de Antonio Mestre Sanchís, Oliva, Ayuntamiento de Oliva, 1983, pág. 243; el subrayado es mío). El lenguaje, en el pensamiento de Mayans, es «instrumento operativo de la razón» (Jesús Pérez Magallón, En torno a las ideas literarias de Mayans, Alicante, Instituto de Cultura «Juan Gil-Albert», 1991, pág. 45), lo que guarda estrecha relación con el ideal estilístico de la claridad. 
tos fundamentales ${ }^{14}$ (aspectos también determinantes en la edición de Azara). Para este propósito resultaba esencial la reedición de textos de erudición y literatura españoles (especialmente del Renacimiento), entre los cuales Mayans había considerado la posibilidad de editar las obras del toledano acompañadas de las anotaciones de sus tres comentaristas ${ }^{15}$; no obstante, la obra y los comentarios de Garcilaso que el valenciano impulsó se incluyen, en la versión del Brocense, en el conjunto de las Opera omnia del catedrático de Salamanca $^{16}$ (precisamente, en el mismo año en que Azara da a las prensas su Garcilaso).

En su edición de Garcilaso, Azara delinea desde el prólogo, configurado en torno a los conceptos de patria, ciencia y lengua, su pertenencia a una corriente ilustrada en auge. Su celo patriótico se ve marcado por la acusación de los males de la nación, sin que pase inadvertida en su desarrollo su aversión a los jesuitas. Su preocupación por el resurgir español en todas sus facetas le conduce aquí a buscar remedio al mal lingüístico y cultural con una mirada al pasado, con la recuperación de un clásico castellano que ha de servir como modelo. No obstante, su patriotismo no le impide censurar el «atraso» en que, en lo respectivo al desarrollo de las ciencias y el lenguaje, tanto en comparación con otras naciones europeas como en relación a su propio pasado glorioso, encuentra situada a España, puesto que confía Azara en que las críticas que pone a la vista del lector y el modelo que le propone en lo tocante a la lengua (y a la poesía, y a la estética) sirvan de acicate para la regeneración de la cultura nacional ${ }^{17}$ (dentro del marco del proyecto

14 Pérez Magallón alude a «la obsesiva preocupación mayansiana por la depuración del lenguaje [...] de toda la ganga poetizante, oscura, retorcida y ostentosa, esforzándose por convertirla en un instrumento operativo de la razón, capaz de abarcar cualquier campo del estudio o el saber», preocupación que convierte en «requisitos irrenunciables» de la escritura «la claridad, la pureza, la propiedad y la naturalidad» (PÉrez Magallón, En torno a las ideas literarias de Mayans, pág. 45).

15 Gregorio Mayans y Siscar, «Gregorio Mayans y Siscar a Manuel Cavero Cortés, 15 de julio de 1758», en Epistolario. Volumen XII (Mayans y los libreros), edición de Antonio Mestre Sanchís, Valencia, Publicaciones del Ayuntamiento de Oliva, 1993, págs. 223-224.

16 Francisco SÁnchez de las Brozas, Opera omnia, Ginebra, 1765-1766.

17 En el cambio de siglo se había impuesto «ya la idea negativa de una España todavía escolástica, en contraposición a una Europa empirista, progresista y librepensadora; una España que, en el ámbito literario, es objeto de burla por su literatura barroca», percepción en que «los franceses (Chapelain, Boileau, etc.) jugaron un importante papel en la configuración de esta imagen. Pero la crítica que más dolor y repercusión provocó entonces en España fue la de Montesquieu en sus Cartas persas (1721), donde, entre otras burlas y refiriéndose al Quijote, afirmó que el único libro español bueno hace ver lo ridículos que son todos los demás escritos en nuestro país» (José Checa Beltrán, «En busca del canon perdido: el siglo XvIII», Studi Ispanici, 5 (2002), págs. 95-115, en pág. 100). Esto despertó el fervor patriótico y acrítico de principios del xVIII. No obstante, a la altura de 1765 y dentro del marco programático del reinado de Carlos III, el patriotismo de Azara se cifra ya mediante la propia crítica al estado lingüístico y cultural nacional en aras de una renovación que haga viable la recuperación del respeto de las otras naciones y encamine a España (y al castellano) hacia el puesto que le corresponde. 
ilustrado de Carlos $\mathrm{III}^{18}$ ). En el prólogo a las Obras Azara argumenta, por tanto, la necesidad de la edición y el objeto de la misma mediante una clara exposición de sus ideas acerca del estado presente de la lengua castellana y de las causas de su declive. En este afortunado texto no es difícil percibir el apasionamiento de Azara en la exaltación de la época imperial y dorada de España ${ }^{19}$, si bien cabe notar que contrarrestado por la, quizás también exacerbada, manifestación de la decadencia posterior $^{20}$. Entre las razones de la degeneración del lenguaje castellano se encuentra, según el aragonés, el lenguaje «culto» del Barroco, como manifiesta en el mismo prólogo mediante apreciaciones subjetivas, ligadas a unos objetivos intereses, en que tilda a los escritores barrocos de ignorantes y pretenciosos ${ }^{21}$.

18 Vid. Ana Isabel Martín Puya, «El Garcilaso de Carlos III: ideas poéticas de Azara», en Entre luces y sombras: la recepción de la poesía del Siglo de Oro de 1700 a 1850, ed. de Begoña López Bueno, Sevilla, Grupo PASO / Universidad de Sevilla, 2014, págs. 151-179.

19 Se inicia la exposición aludiendo al lugar común de la lengua como compañera del imperio, vinculada a Elio Antonio de Nebrija, pero presente también en innumerables escritores. Herrera alude asimismo a este tópico en sus Anotaciones: «an entrado en España las buenas letras con el Imperio i an sacudido los nuestros el yugo de la inorancia» (Fernando de Herrera, Anotaciones a Garcilaso, edición de Inoria Pepe y José María Reyes, Madrid, Cátedra, 2001, pág. 278).

20 Así, por ejemplo, en un pasaje donde a través de la ironía quedan plasmados algunos de los males de la nación, afirma Azara que «en lo que los españoles han trabajado con ahínco hasta nuestros tiempos, exceden con inmensa ventaja a todas las naciones; y si no, que me citen cuál de ellas ha dado a luz tantos y tan pesados volúmenes sobre Aristóteles como nosotros, tantos escritores eminentes en teología escolástica, tantos y tan sutiles casuistas de moral, y tantos profundos comentadores del código y pandectas»; excesiva parece asimismo la consideración de que «raro español ha gastado seis meses para aprenderla [la lengua castellana] por reglas y principios al modo que aprendían la suya los griegos y romanos, siendo infinitos los que han gastado otros tantos años en aprender un mal latín, que en tiempo de Simón Abril y de nuestros buenos preceptores se adquiría en cuatro meses» (Azara, «Prólogo del editor», en Garcilaso, Obras de Garcilaso, [5r.]). No obstante, las quejas de Azara respecto al desconocimiento de la propia lengua están emparentadas con la insistencia de Gregorio Mayans en este mismo descuido, así como en la carencia de una buena gramática para su aprendizaje y enseñanza. Entre los innúmeros ejemplos que podríamos entresacar de las obras del erudito de Oliva se encuentra el siguiente fragmento (perteneciente a la Oración en alabanza de las elocuentísimas obras de Saavedra Fajardo), donde contrapone precisamente versos de Garcilaso, junto a otros de Camões, al mal gusto dieciochesco: «Agradeciera yo que nos dieran desatado en prosa aquel sublime género de hablar: "Cuando me paro a contemplar mi estado" [Garcilaso]; "Las armas y varones señalados" [Camões]; pero ya es cosa vulgar aun decir en prosa: "No blasone el topacio, esmeralda imperfecta, que en hechura de ojos raya engarzado en riscos de Caramania" [Joseph Pellicer de Tovar en el prólogo «Al que leyere» de los Cristales de Helicona, 1650]. De aquí nace que, como el vulgo admira lo que no entiende, yacen hoy despreciados, luchando con el polvo y la polilla, los buenos libros; y comúnmente se aprecian los que solo sirven para calificar la necedad de sus dueños» (cit. en Pérez Magallón, Escritos literarios de Mayans, pág. 129). La consideración y percepción que Azara manifiesta respecto a la decadencia de la lengua y las ciencias en el siglo XVIII concuerda con la imagen que François Lopez nos ofrece acerca de la Ilustración: «fue una voluntad siempre contrariada de sustituir a un antiguo y ominoso desorden, perpetuado y agravado por los Austrias del siglo XVII, un nuevo orden, en lo político, lo social, lo económico, lo religioso, y, claro está, en las artes, las letras y el lenguaje. Un orden a la vez racional, nacional y europeo, porque España, a pesar de su cultura antigua era todavía una nación que existía sobre todo como proyecto» (François Lopez, «Del saber del escritor a la cultura de su tiempo», Bulletin hispanique, 97 (1995), págs. 415-440, en pág. 417).

${ }^{21}$ «Como en el fondo nada sabían, se afanaban por parecer lo que no eran; y, así, hasta en las voces y en el modo de usarlas afectaron su mezquina erudición»; "por ostentar su saber ponían en todo la marca 
En Azara, que se integra dentro de la empresa de dirigismo estatal del reinado de Carlos III, se conjuga el deseo de regeneración a través de la historia nacional, característico de la segunda mitad del XVIII según Vittoria Borsò ${ }^{22}$, con un criticismo delimitado por unos específicos objetivos que determinan la interpretación, corrección y notación ofrecida en su edición «ilustrada» de Garcilaso. El aragonés edita la obra garcilasiana con notas atendiendo a una finalidad divulgativa. Es preciso que los clásicos castellanos lleguen al mayor número de gente posible para frenar el avance de la corriente proveniente del barroco, que ha empobrecido y oscurecido el lenguaje, entre tantos requiebros de falsa erudición. El carácter divulgativo de su empresa le lleva a adoptar una vía más práctica que la abundancia de erudición de Mayans ${ }^{23}$. Sin contacto directo previo entre ambos pensadores, Azara sigue un camino pautado que le sea útil en sus propósitos y nos brinda un Garcilaso dieciochesco únicamente anotado para orientar la lectura (adecuada a sus fines), ya claramente dirigida desde las ideas vertidas en el prólogo.

Aunque Azara afirma haber cotejado siete ediciones previas de Garcilaso y un manuscrito ${ }^{24}$ y haber «enmendado» las numerosas faltas que presentaban, no es esta una edición relevante (ni tan siquiera mínimamente), como ya hemos mencionado, en lo que a la crítica filológica se refiere. No obstante, esto no es índice de un escaso interés de Azara por la edición o un lastre en su capacidad como editor; más bien, si tenemos en cuenta los presupuestos, juicios e intención manifiestos en el prólogo, así como las lecciones singulares y el resto de decisiones en lo tocante a la fijación textual, llegaremos inevitablemente a la conclusión de que era otro el tipo de «correcciones» y «enmiendas» pretendido por el aragonés. Si Garcilaso iba a ser un modelo lingüístico y literario, si iba a ser modelo del buen hacer del escritor erudito, conocedor de los clásicos,

de la latinidad»; «sin más fin, a mi entender, que el de manifestar sabían el origen de estas voces» (Azara, «Prólogo del editor», [5v.]).

22 «En vez de en una conciencia crítica, la búsqueda de la historia desemboca [...] en la preocupación por encontrar imágenes históricas idóneas para el fomento de la regeneración, necesaria para la construcción de lo que se llamó patria o nación. El motivo que impulsa la historiografía es, de hecho, la percepción de la decadencia cultural y la búsqueda de una compensación en los modelos de los antepasados, cuyo ejemplo sirve como base para adelantar progresos y forjar la identidad nacional» (Vittoria Borsò, «Juan Andrés. Prodesse et Delectare. Historia, política y literatura», en Juan Andrés y la teoría comparatista, ed. de P. Aullón de Haro, J. García Gabaldón y S. Navarro Pastor, Valencia, Biblioteca Valenciana, 2002, págs. 113-138, en págs. 116-117).

23 Me refiero en concreto a la intención de Mayans de recoger en una sola publicación las notas de todos los comentaristas de Garcilaso, ya mencionada, frente a la brevedad de las recogidas por Azara, compendio, en su mayor parte, de las de Sánchez de las Brozas, Herrera y Tamayo.

24 Respecto al «interesado» cotejo de ejemplares realizado por Azara y la más que probable existencia del manuscrito mencionado en el prólogo, véase MARTín Puya, Las «Obras de Garcilaso». 
respetuoso con las normas, preocupado por el uso (elegante, claro, natural) del castellano, de un castellano puro, las correcciones habrían de redundar en este sentido $^{25}$. La fijación textual realizada por Azara trasciende los límites de lo filológico en favor de un estilo neoclásico que presentar al lector dieciochesco: no solo a través de la adopción de determinadas variantes de las impresiones previas y del desconocido manuscrito que Azara afirma haber cotejado, sino también mediante la introducción de numerosas lecciones singulares (esas correcciones de errores a que se refiere el aragonés en carta a Mayans ${ }^{26}$ ).

Similar función cumple el aparato de notas que acompaña a los poemas, con el que se sustenta y refuerza el ideario explicitado en el prólogo, lo que queda reflejado en sus propias palabras preliminares: «Para no caer en los mismos inconvenientes [que los comentaristas anteriores], me he propuesto estampar unas anotaciones que aclaren las obscuridades del texto y hagan ver la habilidad y juicio con que Garcilaso supo imitar, y muchas veces mejorar, los pasajes más bellos de los poetas antiguos» ${ }^{27}$; a lo que añade: «Garcilaso se hizo poeta estudiando la docta Antigüedad: las notas lo prueban, y este es el modelo que presento a mis paisanos» ${ }^{28}$ (El subrayado es mío).

El concepto de imitación en sus dos vertientes, imitación de la naturaleza e imitación de modelos, va a ser crucial en el pensamiento de los neoclásicos

25 Como ha indicado María José Rodríguez Sánchez de León, «Azara encuentra en Garcilaso una autoridad que oponer al desconocimiento de la lengua castellana que delata a los malos traductores. La divulgación de su poesía y la anotación de la misma se realizan con objeto de adoctrinar sobre las ventajas de un estilo tan propio, sencillo, preciso y elegante como el garcilasiano» (María José Rodríguez Sánchez dE LEón, «La canonización de Garcilaso de la Vega en la historia literaria de los siglos XVIII y XIX», Dieciocho: Hispanic Enlightenment, 25:2 (2002), págs. 243-254, en pág. 244).

26 Se trata de la carta datada el 13 de febrero de 1766, escrita en respuesta a una previa enviada por el valenciano con motivo de la edición de Garcilaso. Azara se muestra humilde antes las palabras de Mayans, considerando que la obra «es de bien poca estimación», a lo que añade que su labor como editor se ha limitado a «poner en limpio a Garcilaso, y escoger entre las notas que otros habían amontonado, las que me han parecido más a propósito y necesarias, corrigiendo el texto de las muchas erratas que lo desfiguraban» (Amparo Alemany Peiró, «El embajador Azara y los hermanos Mayans», pág. 761). Efectivamente, los comentarios de Azara se reducen, en su mayoría, a una selección de fragmentos de los de Sánchez de las Brozas, Herrera y Tamayo, en menor medida. Los del primero, generalmente, le resultan útiles para señalar las fuentes de imitación, de las que apunta las referencias a los principales autores grecolatinos y a algunos italianos; de Herrera, además de algunas fuentes, recoge (de modo más abreviado y selecto) notas explicativas sobre aspectos históricos, mitológicos y, en ciertos casos, lingüísticos; Tamayo, por su parte, aparece en contadas ocasiones. A estas notas añade Azara algunas de su propia cosecha, sobre estructuras sintácticas y vocablos extranjeros, o sobre determinados usos lingüísticos a través de cuya explicación pretende aclarar el sentido de los versos de Garcilaso (véase Martín Puya, Las «Obras de Garcilaso»).

27 AzARA, «Prólogo del editor», [8r]. Las notas con que Azara acompaña al texto garcilasiano redundan en lo sostenido en el prólogo, cuyas ideas tratan de justificar (en este sentido, por ejemplo, se recogen las principales fuentes de imitación, que atestiguan la erudición de Garcilaso y su clasicismo atento a la auctoritas), ofreciendo unas pautas para leer a Garcilaso en clave modélica neoclásica (e imitable).

28 Azara, «Prólogo de editor», [8v]. 
y en el del propio Azara, como manifiestará posteriormente en su «Comentario al Tratado de la Belleza»: «Toda la finura del arte consiste, pues, como dice Mengs, en saber escoger bien, imitando lo bello y lo necesario, y descartando las menudencias y lo superfluo» ${ }^{29}$. Aunque en este pasaje se refiere el aragonés a la imitación de la naturaleza ${ }^{30}$, esta consideración es extrapolable a la imitación de modelos, a la necesidad de escoger bien, como ya había señalado Mayans ${ }^{31}$. La misma idea se hace explícita en el prólogo de 1765.

Consciente de la situación de decadencia en que se hallan las letras y ciencias españolas, Azara publica su edición como parte de una empresa mayor con la que se persigue «atajar los progresos del mal»: el patriotismo de Azara no le impide realizar una crítica (no libre de prejuicios y apreciaciones subjetivas) acorde a unos presupuestos racionalistas sobre la propia nación, y producida en beneficio de una mejora, de la generación de unas mejores condiciones para el desarrollo de la lengua, de la cultura y de las ciencias. La conclusión alcanzada nos sitúa, una vez más, en la estela del pensamiento mayansiano, de la Real Academia $^{32}$ y, también, del camino recorrido por la Imprenta Real de la Gaceta (también como Imprenta Real ${ }^{33}$ ) en las décadas siguientes: «renovar los escritos de los patriarcas y fundadores de la lengua castellana», cuya sola lectura proporcionará «ejemplos dignos de seguirse» ${ }^{34}$ y restituirá la «pureza y elegancia» del castellano ${ }^{35}$. La clave radica no ya solo en la selección de los escritores

29 José Nicolás de AzARA, «Comentario al Tratado de la belleza de Mengs», en Obras de Antón Rafael Mengs, Madrid, Imprenta Real, 1780, pág. 71.

30 Su concepción de la imitación reside en la selección de las partes más bellas y perfectas de distintos modelos de la naturaleza para crear la perfección artística: la belleza ideal de Mengs.

31 La trascendencia de la adopción de buenos modelos es idea recurrente en la obra mayansiana. Así, por ejemplo, afirma el valenciano que «[la habla española] se adquiere con solo oír o con la lectura y la imitación de los buenos escritores, que son pocos, y por eso es menester gran juicio para distinguir y elegir los mejores» (Gregorio Mayans y Siscar, Rhetórica, tomo II, Valencia, 1757, pág. 18). De manera similar, en los Orígenes de la lengua española se encuentra la lectura de «los mejores autores para imitarlos» entre las pautas que ofrece para la adquisición de un buen uso (con propiedad, elegancia, etc.) de la lengua (Gregorio MaYans y Siscar, Orígenes de la lengua española, tomo II, Madrid, Juan de Zúñiga, 1737, pág. 198).

32 La Real Academia es aludida, aunque sin excluir a otros «sabios», al hacer mención a la necesidad de fijación de la lengua, aspecto en que estos sabios «tienen razón» (AzarA, «Prólogo del editor», [7r.]).

33 Vid. Gabriel Sánchez Espinosa, «La producción editorial del despotismo ilustrado: la Imprenta Real», en Imprenta Real: fuentes de la tipografía española, edición de J. M. Ribagorda, Madrid, AECID, 2009, págs. 72-85.

34 Mayans había apuntado que «mal puede escribir con eminencia quien aún no conoce cuáles son los mejores libros» (en carta a su padre, 1721; cit. en Jesús GuTIÉRREZ, «Mayans y sus primeros ensayos críticoliterarios», Dieciocho: Hispanic Enlightenment, 5:2 (1982), págs. 100-111, en pág. 101).

35 La idea de que solo a través de la lectura de los clásicos se adquiere el buen gusto será repetida hasta la saciedad en la segunda mitad del XVIII. La encontramos muy explícitamente en el mencionado prólogo de Vicente de los Ríos a las Eróticas de Villegas: «solo el buen gusto bebido en los originales de la antigüedad basta para perfeccionar a los que han nacido poetas» (pág. XI). De hecho, en este mismo escrito encontramos también justificada la valía de Villegas de un modo muy similar a como era habitual autorizar la coronación 
concretos, sino también, en primer lugar, en «la época que se debe elegir» ${ }^{36}$. El modelo para el desarrollo del pensamiento ilustrado de Azara y adecuado a su concepción neoclásica es, evidentemente, el «siglo del buen gusto» (frente a los del periodo barroco): «Los que escogen la [época] de la corrupción no siguen buen camino, y, al contrario, debemos trabajar y afanar con la persuasión y el ejemplo para que se tomen por modelo los autores que escribieron en el siglo del buen gusto» ${ }^{37}$. Es decir, el gusto que los neoclásicos «defienden, el único aceptable, por estar apoyado en la "razón", en "las autoridades" y en los modelos clásicos, antiguos y renacentistas, extranjeros y españoles. Es un gusto que se relaciona con determinados presupuestos morales y se define mediante un conjunto de reglas y patrones» ${ }^{38}$. Por contraposición, el «ejemplo paradigmático» del mal gusto «es el de los defensores del barroco; más concretamente, de los defensores del ingenio sin la guía del juicio, de los partidarios de una literatura nacional no sujeta a reglas universales» ${ }^{39}$. La oposición entre uno y otro estilo se corresponde con la preponderancia concedida, en cada caso, a los miembros del par ars e ingenium.

Aunque vemos desde un primer momento que Azara se muestra enormemente interesado por el lenguaje, tal actitud no proviene de la concesión de mayor importancia a la forma que al contenido; por el contrario, su propuesta de Garcilaso como modelo responde precisamente al deseo de retornar a una llaneza y sencillez, a un estilo lingüístico (y estético) que facilite la transmisión y comprensión del contenido, lo fundamental en una concepción racionalista y neoclásica ${ }^{40}$.

En definitiva, la edición de las Obras de Garcilaso de la Vega, ilustradas con notas construye y establece el texto garcilasiano como modelo linguiístico y literario (en oposición al estilo barroquizante) para el lector dieciochesco, basándose en dos aspectos esenciales: la imitatio (de autoridades) y la represen-

de Garcilaso, mediante los argumentos de estilo linguíístico, imitación e incorporación de metros clásicos, que sitúan al castellano a la altura del latín (Vicente DE LOS Ríos, «Memorias de la vida y escritos de Esteban Manuel de Villegas», en Esteban Manuel de Villegas, Las Eróticas, y traducción de Boecio, Madrid, Sancha, 1774, págs. XIII-XIV).

36 AzAra, «Prólogo del editor», [7r.].

37 AzAra, «Prólogo del editor», [7r.].

38 José Checa Betrrán, Razones del Buen Gusto. Poética española del neoclasicismo, Madrid, CSIC, 1998, pág. 21.

39 Checa Beltrán, Razones del Buen Gusto, pág. 21.

40 Como ha indicado Checa Beltrán, «Esa prioridad que los teóricos dieciochescos conceden a la enseñanza (docere) frente al deleite (delectare), y a las reglas (ars) frente a la capacidad natural del artista (ingenium), se corresponde con la mayor importancia que dan al contenido de la obra literaria (res) frente a [la forma] (verba), que prima los aspectos puramente formales de la composición poética» (Checa BeLtrán, Razones del buen gusto, págs. 118-119). 
tatividad misma del toledano como erudito que creó su obra a partir del conocimiento de los clásicos, principalmente de la Antigüedad (es decir, que él mismo imitó a los buenos modelos $)^{41}$. De este modo, el valor ejemplar de Garcilaso no se reduce a su calidad y estilo poéticos, sino que su misma obra es manifiesto de su ejemplaridad como modelo de escritor (erudito e imitador de los mejores), como prueban las notas ${ }^{42}$. No cabe duda de que esta idea está relacionada con la relevante afirmación de que «el poeta que no haya imitado a los antiguos no será imitado de nadie», incluida en el prólogo basándose en la autoridad de Boileau y del Brocense ${ }^{43}$.

\section{Garcilaso, ¿criticado?}

Rodríguez Sánchez de León incluye a Azara entre aquellos autores que «eximen a Garcilaso de toda culpabilidad atendiendo al momento en que vivió» (lo que en el caso del aragonés se debería al hecho de sentirse «obligado dada su condición de editor y continuador de la labor emprendida por Sánchez de las Brozas y Fernando de Herrera» ${ }^{44}$ ). Sin embargo, tanto en el prólogo como en las notas Azara parece desarrollar aquella máxima, previamente empleada por Mayans, de apuntar lo censurable, sin que esto reste mérito o haga perder el valor modélico del autor tratado, con objeto de evitar la imitación y perpetuación de los errores. La selección del poeta como modelo conducirá, no obstante, a la acentuación de las virtudes de la escritura de Garcilaso, quedando, de este modo, claramente evidenciado y distinguido lo que merece ser imitado y lo que no. Ya nos dice el aragonés en el prólogo que en la novedad de «colocar el consonante en medio del verso al modo de los árabes fue poco feliz y menos

41 Estos aspectos han sido desarrollados en mayor profundidad en MARTín PuYa, Las «Obras de Garcilaso». Precisamente, este ajustarse a la imitación y a la razón que se resalta en la obra garcilasiana durante buena parte del XVIII será objeto de crítica a finales de siglo y principios del XIX, cuando comience a instaurarse el «estilo espiritoso» en la poesía, bandera de los «neoclásicos modernos», según la denominación de Checa Bettrán, Razones del buen gusto, pág. 20. A juicio de Quintana, en el xviII, «la [poesía] castellana [...] ganará en decoro, en corrección y en saber, será más cuidadosa de evitar defectos que, atrevida y ambiciosa, de producir bellezas; querrá más bien contentar la razón que regular el oído y arrebatar la fantasía; tendrá, en suma, con más corrección y mejor gusto, menos libertad, menos riqueza, menos encanto, menos halago» (Manuel José Quintana, Obras completas, Madrid, B. A. E., 1852, pág. 146).

42 Dado el carácter utilitario de las notas, cuyo objeto es probar la adecuación de Garcilaso a los presupuestos afirmados en el prólogo y su idoneidad como modelo, su incorporación y brevedad responde a la concepción de que «en todas las cosas lo accesorio debe servir a lo principal; lo ocioso es fealdad en vez de hermosura» (AzARA, «Prólogo del traductor», en Conyers Middleton, Historia de la vida de Marco Tulio Cicerón, tomo I, Madrid, Imprenta Real, 1790, pág. 81).

43 Azara, «Prólogo del editor», [8v.].

44 Rodríguez Sánchez de LEón, «La canonización de Garcilaso», pág. 246. 
imitado» ${ }^{45}$ (y, como se manifiesta unos párrafos más adelante, la imitación, el ser imitado, es índice de la importancia de un autor). A esto se suma la censura en las notas, aunque no se trata de una crítica en profundidad ni feroz, del uso lingüístico en los sonetos (especialmente). El oscense justifica los usos censurables de Garcilaso atendiendo al origen italiano de los mismos y su frecuencia en la época, pero sin eximirle por completo de responsabilidad. Si bien no se ceba en la crítica, tampoco los elogios destinados al poeta toledano sobrepasan la expresión comedida de los mismos a lo largo de la edición, y se evidencian por la acumulación de referencias a los modelos grecolatinos, principalmente, más que por el énfasis dedicado a composiciones o fragmentos determinados. Incluso para mostrar su clara preferencia por el estilo y composición de la Égloga I, a pesar de que Azara la sitúa entre las mejores de todas, mantiene un tono moderado (posiblemente considerando la mayor efectividad que podría obtener en favor del calado de su discurso, neoclásico, conforme a la apariencia de objetividad pretendida y acorde al modelo textual de la persuasión, que no con el exceso y descaro que supondría, bajo tales presupuestos, una exaltación desmedida): «Esta égloga es sin comparación la más bella de Garcilaso y una de las mejores que se han escrito [...] Toda esta égloga está llena de imitaciones de los mejores pasajes de los más famosos poetas latinos e italianos. Nos contentaremos con insinuar algunas no más» (pág. 1).

Esta circunstancia se ve corroborada por las propias palabras de Azara en su edición de las Obras de D. Antonio Rafael Mengs ${ }^{46}$, insertas en nota a una carta de Mengs a Falconet en que Azara critica la obra de este porque zahiere en ella a escritores clásicos y modernos de modo burlesco. En defensa de Plinio, afirma Azara:

Mil autores han revelado los errores de Plinio, y más de mil han admirado su mérito. El hombre honrado y de carácter honesto, cuando halla los errores, los advierte con moderación para evitar que otros caigan en ellos, pero no refriega las

45 Aunque no se detiene Azara en el análisis de este punto, cabe reseñar que está devaluando la adopción de un modelo ajeno al grecolatino. Es significativa las contraposición entre ambos modelos que nos ofrece Forner en su Oración apologética: «Ninguna cosa más espléndida, más bella, más agradable que la Filosofía de los griegos hasta en sus delirios; ninguna más torpe, más fea, más inelegante que la de los árabes, cuya natural incultura, unida al ansia de curiosear, produjo un saber menos culto, que imitado por quienes, en vez de mejorarle, le acabaron de pervertir, ha tenido después largos tiempos oprimidos los vuelos del entendimiento, y perdido el buen gusto y la elegancia de las doctrinas en el escabroso laberinto de las disputas (Juan Pablo Forner, Oración apologética de la España y su mérito literario, ed. de Jesús Cañas Murillo, Badajoz, Diputación Provincial, 1997, págs. 83-84).

46 José Nicolás de Azara, Obras de D. Antonio Rafael Mengs, primer pintor de cámara del rey, Madrid, Imprenta Real, 1797 (es anterior la edición en italiano: Opere di Antonio Raffaello Mengs, primo pittore della maestà di Carlo III Re di Spagna, Parma, Stamperia Reale, 1780). 
llagas con pimienta y vinagre, como hace Falconet. Debía haber iluminado a este el juicio que hace de Plinio Mr. De Buffon, que no ignora, cierto, los defectos de aquel naturalista, pero los ve como los hombres de su mérito ven las cosas, con humanidad y juicio; y por eso su elogio de Plinio será eterno, como sus demás obras ${ }^{47}$.

Los clásicos no dejan de serlo por realizar una crítica sobre ellos, pues pocos, o ninguno, hay perfectos. Sin embargo, la crítica (moderada) debe existir, con el objeto de que no caigan otros en sus mismos errores. En esto coincide Azara con Mayans, y esto aplicó en su edición de la obra garcilasiana.

Muestra de la compatibilidad en el modelo del elogio y la crítica es la nota al «Soneto III», donde Azara emite el siguiente juicio: «Los seis últimos versos forman una antítesis ridícula, y con trabajo se descubre lo que quieren decir». Aunque previamente ha indicado el editor que en este poema sigue el toledano a Sannazaro y Petrarca, especifica que la imitación se da al inicio del soneto, mientras que los versos censurados son «los seis últimos».

En el «Soneto V», por otra parte, Azara menciona la influencia de los italianos sin dejar de reprender su imitación por parte de Garcilaso. Reproducimos, por su interés, la nota completa:

Los versos 5 y 9 de este soneto son durísimos. Garcilaso, en este y en casi todos sus sonetos, habla de amor con tantas figuras y con ideas tan poco naturales, tan extraordinarias y confusas, que apenas se acierta con lo que quiere decir. De los italianos, a quien imitó, contrajo este mal gusto de espiritualizar, por decirlo así, las cosas más naturales y sencillas, envolviendo unos pensamientos claros en sí con mil rodeos y contraposiciones, que cansan en vez de agradar. Sus églogas son cosa muy distinta (pág. 160).

El interés de Azara parece cifrarse, más que en redimir de responsabilidad a Garcilaso, en aprovechar para censurar la introducción de unos vicios (vinculados posteriormente al barroco) cuyo origen sitúa en los italianos ${ }^{48}$. Efectiva-

47 Azara, Obras de D. Antonio Rafael Mengs, pág. 174. El subrayado es mío.

48 El modelo que Azara está proponiendo es el neoclásico; la imitación útil es la de los grandes autores grecolatinos (conviene no olvidar que «Garcilaso se hizo poeta estudiando la docta Antigüedad: las notas lo prueban, y este es el modelo que presento a mis paisanos» [AzARA, «Prólogo del editor», 8v.]); por este motivo, se explicitan en la edición de Azara las virtudes del estilo elogiado, al tiempo que se manifiesta también la preponderancia de estos modelos y del propio Garcilaso sobre los escritores de otras lenguas romance, donde destacan los italianos. Recordemos que desde finales del XVII se venía desarrollando en Europa la polémica sobre el origen del mal gusto a partir de la aparición de las obras del padre Bouhours en Francia. El debate se reavivó especialmente en la segunda mitad del XvIII, en confluencia con las críticas a la literatura y cultura españolas venidas de plumas extranjeras, contexto en que surgirían obras como el Saggio storico-apologetico 
mente, aunque la crítica a los sonetos tiene un claro componente nacionalista, no excluye el aspecto estilístico: apunta a este tanto de un modo explícito, a través de la presentación de los defectos de los poemas, como mediante la identificación de las virtudes garcilasianas con las composiciones clásicas, vinculadas al mundo grecolatino, cuyo conocimiento e imitación son, para Azara, la fuente del buen gusto.

De este modo, la crítica que afecta a estas composiciones, que también señala a Garcilaso, no es motivo para que el toledano deje de ser un modelo digno y elevado para la imitación, sino que conviene, más bien, la revelación de los aspectos que no deben ser imitados, puesto que apuntan hacia el mal gusto que se pretende desterrar. Hasta tal punto es así que se hace explícito el sintagma «mal gusto» (llevado a sus extremos por los poetas cultos sobre los que se ironizaba en el prólogo); en este caso, se indica, «mal gusto de espiritualizar [...] las cosas más naturales y sencillas» (pág. 160). En el Diccionario de Autoridades encontramos que «espiritualizar» es «elevar y constituir en grado u orden espiritual lo que de suyo no lo es, haciendo que pase a otro estado y se repute y considere como cosa espiritual la que antes no lo era», y «considerar como cosa espiritual la que según su ser no lo es, sacándola mediante el discurso y consideración del estado, como de corpórea o terrena al de perteneciente al espíritu» (en su segunda y tercera acepción, respectivamente. El subrayado es mío). La naturalidad, la sencillez, la claridad, abanderadas del buen gusto, se oponen a esta «manía» de espiritualizar mediante la acumulación de figuras, la complejidad y la oscuridad, «que cansan en vez de agradar» (pág. 160). De este modo, este «gusto por espiritualizar» se identificaría en Azara con lo ingenioso y conceptual, y se opondría a la supremacía del juicio en consonancia con su ideal neoclásico ${ }^{49}$.

della letteratura spagnuola contro le pregiudicate opinioni di alcuni moderni scrittori italiani (Saverio LamPILlas, Génova, 1778-1781); Dell'origine, progressi e stato attuale d'ogni letteratura (Juan Andrés, Parma, Stamperia Reale, 1782-1799), y otras.

49 Aunque la edición de Azara es anterior a la aparición de la obra de Juan Andrés, Origen, progresos y estado actual de toda literatura (1782-1799), cabe ahora recordar que el jesuita denominó al nuevo estilo literario de finales de siglo como estilo «espiritoso» o «filosófico», «una manifestación más de una nueva filosofía que fomenta el uso del ingenio a costa del juicio, una filosofía escéptica que nada espera ya del racionalismo ilustrado, y que, consecuentemente, favorece el ingenio y la imaginación» (CHECA Beltrán, Razones del buen gusto, pág. 289). La caracterización que hace Andrés de este estilo ha llevado a Checa Beltrán a afirmar que «Juan Andrés se refiere al Barroco como categoría ideal, como estilo que aparece en las épocas de corrupción del gusto: cuando el padre Andrés habla del "estilo espiritoso" como un nuevo gusto que está cobrando fuerza hacia 1780, no solo se refiere a él (muy negativamente) como a un estilo nuevo, sino también como la resurrección del gusto por el ingenio — sin el freno del juicio y razón- que existió en el siglo Xvir y en otros siglos "corrompidos"» (José CHECA BELTRÁN, «Recepción de los modelos líricos áureos en el siglo ilustrado», en Entre sombras y luces: la recepción de la poesía del Siglo de Oro de 1700 a 1850, dir. por Begoña López Bueno, Sevilla, PASO / Universidad de Sevilla, 2014, págs. 51-79, pág. 56). Vid. José Checa BeLtrán, «Poesía y filosofía: Juan Andrés y el “estilo espiritoso" », Revista de literatura, 118, 1997, págs. 423-436. 
Cabría añadir la nota que acompaña al verso 770 de la Égloga II entre los pasajes en que Azara censura un uso por parte de Garcilaso (y, de paso, lo prolijo y gratuito que le parece el respectivo comentario de Herrera, quien, en sus Anotaciones, «dijo cuanto sabía» ${ }^{50}$ ). Se trata, en esta ocasión, del vocablo desbañar, cuya oscuridad viene demostrada por el hecho de que ninguno de los comentaristas previos haya sabido con certeza su significado:

Esta voz es tan extraña en castellano que con dificultad se puede saber lo que quiere decir. El maestro Sánchez no la explica y Herrera nos muele con una pesada digresión sobre el uso de las voces nuevas, sin decirnos lo que significa esta; sin duda, porque no lo supo, pues quien amontonó tantas impertinencias no hubiera omitido una cosa tan esencial. El Diccionario de la lengua ni hace mención de ella. Tamayo de Vargas es el único que se aventura a interpretarla. Según él, desbañar quiere decir 'afligir, congojar', deducido de las lenguas griega y latina, en que $b a$ ñar se toma muchas veces por 'aliviar, refocilar, quitar cuidados' (pág. 48).

Asimismo, respecto al Soneto XIX, Azara señala la dificultad del último terceto, recurriendo al intento de Sánchez de las Brozas por esclarecerlo; concluye apuntando, sin embargo, que «de puro exquisito, es ridículo este modo de explicarse» (pág. 170). Probablemente sea esta misma dificultad que el aragonés encuentra en el último terceto la que le lleve a introducir una lección singular en el verso 14 del soneto.

Como en el caso de Mayans, en Azara, abogar por la imitación de los buenos modelos como medio efectivo para el progreso cultural, literario o linguiístico supone primar el potencial de ejemplaridad de los escritores sobre la configuración de un canon historial superior al del resto de naciones. No significa esto que no actúen ambos en defensa de la tradición autóctona ni que no siembren parangón entre los autores castellanos y los extranjeros; significa, no obstante, que anteponen la reconstrucción de la literatura nacional, para la que creen ineludible la presencia y pervivencia de adecuados modelos, sobre el elogio de lo censurable de los autores que prefiguran el canon ${ }^{51}$. Porque,

50 AzAra, «Prólogo del editor», [8r.].

51 Traemos aquí un pasaje de la Rhetórica de Mayans en que vincula el aprendizaje de la habla española a la lectura e imitación de los buenos escritores, insistiendo, además, en que se debe conocer la presencia de imperfecciones incluso en las obras de estos: «Veamos cómo se consigue [la habla española]. Se adquiere con solo oír, o con la lectura y la imitación de los buenos escritores, que son pocos; y por eso es menester gran juicio para distinguir y elegir los mejores, entre los cuales ciertamente podemos contar [...] de los poetas: a Jorge Manrique, a Garcilaso de la Vega, a Juan Boscán, a Cristóbal de Castillejo, a D. Diego Hurtado de Mendoza, a fray Luis de León, a Gregorio Hernández de Velasco, a Cristóbal de Virués, a Francisco de la Torre, a D. Esteban Manuel de Villegas, a los hermanos Argensolas, y a otros pocos [...] advirtiendo que en 
como señaló François Lopez, el lenguaje «fue el lugar privilegiado, idealmente común, donde aparecieron en plena luz el anhelo de saneamiento, de puesta en circulación de signos de buena ley, por una parte, y, por otra, de restauración (palabra clave, más que otra cualquiera), restauración que implicaba un deseo de restituirlo todo a un primitivo ser, patrimonio antiguo que había de ayudar a construir el futuro de los españoles» ${ }^{52}$. Sin embargo, pasando por el tamiz de la crítica ese patrimonio.

No se trata, por tanto, exclusivamente de dar a conocer los autores a seguir, sino también de revelar los aciertos dignos de imitar y los yerros susceptibles de ser evitados (reseñados para evitarse). No estriba solo la preocupación de estos intelectuales en mostrar la existencia de una tradición literaria renacentista superior a las extranjeras, sino que se antoja insoslayable la necesidad de producir una literatura capaz de imponerse a los méritos del resto de naciones (no solo recuperar el pasado, sino también construir un presente, y un futuro):

Cierta es la competencia con las más cultas de Europa; superiores son nuestras armas, quiero decir nuestra lengua, si la manejamos tan bien como nuestros mayores la espada. No es muy incierta la esperanza de conseguir la victoria, como a la diligencia de los extraños corresponda la nuestra. Fue elocuentísima Atenas. Quiso competirle Roma, pero no la pudo igualar, así porque no fue tan sabia como porque la lengua no era tan expresiva y copiosa. La nuestra lleva una gran ventaja a las europeas todas. ¿Qué falta, pues, sino superar a los extraños, o a lo menos igualarlos, en el saber y uso? [...] si solamente se imitan los que supieron hablar, si se procura imitar con intención de vencer, como con grande acierto imitó Platón a Cratilo y Arquitas [...] si se procura, digo, imitar fija más la mente en la perfección universal que requiere el arte que en la particular observación del artificio de alguno ${ }^{53}$.

Un racionalismo puesto al servicio de un pragmático sentimiento (y deber) patriótico; una mirada al pasado para la regeneración de las letras castellanas, puesto que, tal vez atendiendo a Mayans, consideraba el aragonés que la lectura de los buenos modelos contribuía a una práctica de la escritura adecuada para conducir los avances y progresos de la razón ilustrada.

\footnotetext{
casi todos los referidos, así poetas como prosistas, aunque se halla la propiedad del estilo falta muchas veces la enmienda, porque como no se ha escrito una buena gramática de la lengua española se suele pecar contra los preceptos que ella debiera señalar» (Gregorio MaYans y Siscar, Obras completas, III, ed. de Antonio Mestre Sanchís, Oliva, Ayuntamiento de Oliva, 1984, pág. 319).

52 Lopez, «Del saber del escritor a la cultura de su tiempo», pág. 417.

53 El pasaje pertenece a la «Oración que exhorta a seguir la verdadera idea de la elocuencia española». Recogido en Pérez Magallón, Escritos literarios de Mayans, págs. 149-150. El subrayado es mío.
} 
En el prólogo de las Obras de Garcilaso se unen la exaltación de la gloria imperial, que se aleja en el tiempo, y la dura crítica a la posterior degradación política, cultural y lingüística de la nación. La argumentación de las causas de desvirtuación de la imagen de España en Europa precede a la plasmación del deseo de regeneración de unas virtudes legítimamente nacionales que requieren la recuperación de los «escritos de los patriarcas» de la lengua y cultura españolas. La propuesta de Garcilaso como modelo lingüístico y estilístico, salvándose lo censurable, cifrado esencialmente en los sonetos, redunda en el concepto de pureza, y ya sabemos que

[...] el precepto de pureza de la poética del siglo XVIII impuso la pérdida del multilingüismo de tipo popular que, en el siglo anterior, había permitido una relativa autonomía de las letras, abriendo sendas indirectas con la censura «moral». La claridad clásica, por lo contrario, se transformó en un arma prescriptiva de la «normalidad» moral y de la cultura nacional ${ }^{54}$.

De manera consecuente al propósito de su desempeño como agente político ilustrado, el aragonés propugna a través de las Obras de Garcilaso de la Vega, presentado como modelo, un lenguaje neoclásico, donde la pureza castellana se vincula ideológicamente al ideal de la razón como justo tamiz para el adelantamiento de las ciencias, de la cultura y de las costumbres nacionales ${ }^{55}$.

\section{El soneto, ¿cauce para la razón o para el ingenio?}

Desde nuestra concepción actual acerca del soneto y de la razón podría, tal vez, sorprendernos, en un primer momento, que Azara, agente ilustrado, desprecie el valor de los sonetos garcilasianos. Rivers señaló, en 1992, que «we can

54 Vittoria BoRsò, «Juan Andrés», pág. 120.

55 Clara manifestación del ideal lingüístico defendido por Azara lo encontramos en el prólogo que incluyó en su traducción de la obra de Middleton sobre Cicerón: «no se habla para otra cosa que para darse a entender con facilidad [...] creo que el gran mérito de un autor consiste en escribir cosas útiles y en empeñar a que se lean, y que con frases simétricas y relimadas suele lograrse hacer bostezar o tiritar de frío. A fuerza de preceptos echan grillos a las lenguas, las cuales, con la prudente libertad y el ejercicio, se enriquecen, se pulen, se suavizan y se hacen más armoniosas y más manejables para tratar cualquier asunto. La nuestra se debe quejar de los cultos y discretos del siglo pasado y de los gramáticos de este, por haberla despojado no solo de muchas palabras, frases y modos de hablar muy significativos y enérgicos, sino también de las elisiones, los apóstrofes y otras licencias que constituyen la belleza de las lenguas más cultas, despreciando el ejemplo y autoridad de los grandes hombres que comenzaron a usarlas y nos pusieron en camino de tener un idioma flexible, poético y musical, diferente del prosaico, como le tuvieron los griegos y le tienen hoy los italianos» (AzARA, «Prólogo del traductor», págs. 80-81). 
see that from its beginnings the sonnet was structured not only by versification but by a process of reasoning, often in terms of cause and effect ${ }^{56}$. No obstante, la estructura del soneto se ha visto tradicionalmente vinculada al despliegue técnico y formal necesario para plasmar, en breve espacio y en adecuación a una fuerte reglamentación métrica, una idea. Aunque existe una tradicional relación del soneto con la lógica, este supone una estructura cerrada, formalizada, y que requiere la concisión; es dada para la expresión de un razonamiento, pero el razonamiento queda aprisionado por unos requerimientos métricos muy precisos, que convierten al soneto, a su vez, en difícil cauce para un lenguaje que responda a la naturalidad sintáctica o a la claridad y sencillez por que aboga el neoclasicismo. Más bien, por el contrario, el soneto es, de manera análoga a lo que ocurre con la décima, adecuado molde para los alardes del ingenio y la pirotecnia retórica. De hecho, «el soneto es la forma culta preferida de Lope, porque en ella resplandece más el concepto y porque es forma tersa y limpia que encierra un pensamiento en extremo condensado» ${ }^{57}$. El propio Herrera se referirá a esta como «la composición "de mayor artificio i gracia" que tienen la poesía italiana y española», aludiendo a su dificultad, que hacía de este metro «dino de ser preciado en mayor estimación ${ }^{58}$. Para Herrera, resplandecen en el soneto,

[...] con maravillosa claridad i lumbre de figuras i esornaciones poéticas la cultura i propriedad, la festividad i agudeza, la manificencia i espíritu, la dulçura i jocundidad, l'aspereza i vehemencia, la comiseración i afetos, i la eficacia i representación de todas. I en ningún otro género se requiere más pureza i cuidado de lengua, más templanza i decoro; donde es grande culpa cualquier error pequeño; i donde no se permite licencia alguna ni se consiente algo que ofenda las orejas; i la brevedad suya no sufre que sea ociosa o vana una palabra sola. I por esta causa su verdadero sugeto i materia deve ser principalmente alguna sentencia ingeniosa i aguda, o grave, i que meresca bien ocupar aquel lugar todo [...] huyendo la oscuridad i dureza, mas de suerte que no descienda a tanta facilidad que pierda los números i la dinidad conveniente ${ }^{59}$.

56 Elías S. Rivers, «Some species of the sonnet as genre», en Muses and masks: some classical genres of Spanish poetry, Newark, University of California, 1992, pág. 34.

57 «Lope de Vega, poeta», Obras completas, vol. 4, ed. de M. Albert Robatto y E. Faría Cancel, Universidad de Puerto Rico, 2001, pág. 394.

58 Herrera, Anotaciones, pág. 65.

59 Herrera, Anotaciones, pág. 267. 
Es evidente que la concepción herreriana del soneto choca con el interés estilístico y lingüístico de Azara, especialmente en lo referido al indudable artificio que requiere, al entender del sevillano, y en la materia ingeniosa. Recordemos, además, con Checa Beltrán, que «el "buen gusto" no era partidario de un uso excesivo de términos cultos o nuevos, ni de conceder gran relevancia a la sonoridad y brillantez de la palabra», en una reacción «contra la desmedida importancia concedida por los autores barrocos a la brillantez del lenguaje. Se censuraba a estos por sus excesos verbales, su abuso de recursos retóricos, su estilo hiperbólico y por el frecuente uso de metáforas atrevidas» ${ }^{60}$.

Pese a todo esto, y pese al afán de Azara por encarecer la imitación de los clásicos grecolatinos por parte de Garcilaso, el aragonés no realiza en ningún momento una censura específicamente dirigida al metro italiano, sino que son los otros factores de la imitación los que son críticados como productores del mal gusto. Así, vemos que el Soneto X, cuyos «dos primeros versos son imitados de Virgilio», «es, sin comparación, el más dulce y suave» de los de Garcilaso (pág. 164); tampoco este juicio (derivado de Herrera, que consideraba dulcísimo y suavísimo el poema virgiliano) supone un elogio excesivo, puesto que Azara pretende recalcar que cuando más loables e imitables son las composiciones de Garcilaso es cuando beben de las fuentes grecolatinas clásicas.

Si bien las ideas poéticas de Azara, como integrante de la facción neoclásica, revelan la alta concepción del ars como insalvable partícipe en la creación poética, su alcance y manifestación se adquieren y proyectan a través de la práctica de la imitatio/emulatio en mayor medida que a través de unas reglas aprendidas. Al mismo tiempo, si el predominio de res sobre verba confiere la primacía al contenido sobre la forma, el propio carácter utilitario de la escritura vinculada al ideal ilustrado y al dominio de la razón interviene en favor de la sencillez, naturalidad y claridad del lenguaje, tanto en poesía como en prosa. Teniendo esto en cuenta, los juegos retóricos a que se presta habitualmente el breve espacio del soneto no parecen adecuarse como presumible cauce formal para una expresión poética adecuada a la concepción neoclásico-ilustrada del aragonés. No cabe duda, además, de que sus Obras de Garcilaso reflejan y tratan de transmitir (y de extender) la superioridad de las fuentes de la antigüedad grecolatina como manantial directamente conducente a los logros de la tradición romance en castellano, cuyos autores quedan, de este modo, legitimados como modelos para la recuperación del buen gusto en las letras contemporáneas.

La menor atención que Azara presta a los sonetos, destacada, además, por la modificación de la dispositio tradicional de la obra garcilasiana, que

60 Checa BeLtrán, Razones del Buen Gusto, pág. 114. 
los situaba en el primer lugar de una obra configurada en orden descendente, concuerda con el descenso del interés respecto al metro italiano en el XVIII. Hemos de decir que el soneto no goza de gran prestigio en las filas neoclásicas en relación con el periodo áureo. La dificultad con que se asocia la composición de sonetos provoca la reducción del número de poemas publicados por los neoclásicos bajo esta estructura, como demuestra la escasa aparición de los mismos en las obras de Meléndez Valdés (20 publicados y 33 escritos), y, sobre todo, de Cadalso (7) y Jovellanos (6), o su inexistencia entre las de Quintana y Cienfuegos ${ }^{61}$. Tanto la consideración de la compleja codificación del soneto como la necesidad de una destreza meritoria y una ardua elaboración aparecen expresados en el texto preliminar de la edición de Villegas que realizara Vicente de los Ríos (quien se refiere, como apuntara Boileau, a la escasez de sonetos perfectos en castellano), donde el cordobés, incluso, presenta como prueba del buen juicio del poeta riojano el escaso número de sonetos que se encuentra entre sus obras publicadas, distinguiendo así entre el carácter positivo de la ejercitación en la composición de sonetos y la necesidad de selección a la hora de hacerlos públicos. Quintana, por su parte, aducirá esta misma dificultad, unida a una caracterización del soneto como artificioso y opresor, como argumento para la abolición de este metro de la poesía española; así, sin moderación arremete en el prólogo al tomo XVIII de la colección de Ramón Fernández ${ }^{62}$ contra el soneto del siguiente modo: «¿Cuándo se acabará de desterrar este género de poesía artificioso y pueril, donde la imaginación encadenada ni puede volar ni extenderse, y donde apenas hay otro mérito que el de la dificultad vencida? Jamás un soneto ha podido compensar con sus bellezas el tiempo y el trabajo que se malgasta en componerle» ${ }^{63}$. Para Quintana, el soneto es en exceso restrictivo y (de manera similar a la imitatio garcilasiana ${ }^{64}$ ) limita las posibilidades del despliegue de las capacidades naturales de inventiva y fantasía poéticas.

61 Pérez Magallón, «Introducción», en Leandro Fernández de Moratín, Poesías completas (poesías sueltas y otros poemas), Barcelona, Sirmio - Cuaderns Crema, 2014, pág. 97. Respecto a los sonetos de Moratín vid. Pablo Cabañas, «Los sonetos de Leandro Fernández de Moratín (Algunas observaciones)», en Actas del IV Congreso Internacional de Hispanistas, coord. por Eugenio de Bustos, vol. 1, Salamanca, Universidad de Salamanca, 1982.

${ }^{62}$ Manuel José Quintana, [Prólogo], Poesías inéditas de Francisco de Rioja y otros poetas andaluces, tomo XVIII de la colección de R. Fernández, Madrid, Imprenta Real, 1797, s. p.

63 Quintana, [Prólogo], en nota, s. p. Citado también en María Elena Arenas Cruz, Pedro Estala, vida y obra, Madrid, CSIC, 2003, pág. 173.

64 Recordemos que Quintana considera que la «manía de imitar alteró las buenas dotes con que había nacido Garcilaso» (Manuel José Quintana, «Prólogo», en Poesías escogidas de nuestros cancioneros y romanceros antiguos. Continuación de la colección de D. Ramón Fernández. Tomo XVI, Madrid, Imprenta Real, 1796, pág. x). 
A esto contestará Leandro Fernández de Moratín, que se refiere a este molde «como la más difícil de las composiciones cortas», insertando en sus Poesías sueltas una apología del soneto, donde rebate el duro juicio de Quintana y recupera para esta forma el tópico de la «dificultad vencida», cifrando su defensa, además de en una nómina de poetas castellanos que compusieron algunos sonetos, dice, «iguales en mérito a sus estimadas obras», en la mención de otras composiciones difíciles (épica, comedia, tragedia...) que no por ello dejan de escribirse ${ }^{65}$, porque «si lo que es difícil no ha de intentarse ¿qué podrá escribirse? Nada, sino alguna compilación indigesta de preceptos impertinentes, aplicados a la teoría de las artes, que no hayamos practicado jamás ${ }^{\circ 6}$.

En Moratín encontramos un excepcional defensor aférrimo del soneto, lo que se deja ver, aparte en la mencionada defensa de este género de composiciones, en haber cultivado, y publicado, un número elevado de sonetos para la época (25 escritos, 19 publicados), que llega a situarse por encima del resto de metros empleados en sus composiciones conocidas, y ocupa el segundo lugar en las impresas, viéndose superado por el número de odas (21 odas, 19 sonetos), aunque 9 de estas sean traducciones de Horacio ${ }^{67}$. A esto se une la recopilación manuscrita de una extensa antología de sonetos españoles de diversos autores ${ }^{68}$.

Como hemos visto, para Azara el soneto está vinculado a una concepción ingeniosa de la poesía. La «dificultad vencida» que mencionan Quintana y Moratín supone la oscuridad poética y lo artificioso para el aragonés, estableciéndose un acercamiento entre los sonetos de Garcilaso y el «mal gusto de espiritualizar» (pág. 160, en nota) que Azara identifica con la secta barroca de los «cultos». Salvando las distancias, la desnaturalización del lenguaje que llega a su máximo apogeo en el estilo barroco se manifiesta en unas composiciones que, además, no tienen su origen en las autoridades clásicas.

65 Los ecos de la dificultad del soneto recorren numerosos textos de las décadas finales del xvIII. Enlazando con las ideas vertidas por Moratín, Vicente de los Ríos distingue de manera implícita entre la escritura del soneto y su «publicación» al apuntar como prueba del mérito de Villegas el hecho de haber incluido entre sus poemas impresos muy pocos sonetos: «ya que no consiguió acreditar su numen componiéndolos, quiso manifestar su moderación y juicio no determinándose a publicarlos» (Vicente DE LOS Ríos, «Memorias de la vida y escritos de don Esteban Manuel de Villegas», en Las Eróticas, y traducción de Boecio, Madrid, 1774, pág. XXVI). Cabe señalar que tanto Vicente de los Ríos como José Nicolás de Azara mencionan como referente en sus textos al «gran crítico Boileau», en palabras de Azara pertenecientes al prólogo de 1765.

66 Leandro Fernández de Moratín, Poesías completas (Poesías sueltas y otros poemas), ed. de Jesús Pérez Magallón, Barcelona, Sirmio, 1995, págs. 169-170; aparece como nota al poema 4, «A Flérida, poetisa».

67 Pérez Magallón, «Introducción», pág. 96-97.

68 Hay edición moderna: Joaquín de Entrambasaguas, Sonetos escogidos por Leandro Fernández de Moratín, Madrid, Dirección General de Archivos y Bibliotecas, 1960. 
Si la de Sánchez de las Brozas era la edición de un gramático que reflejaba en sus comentarios un carácter preceptivo vinculado a la retórica clásica, sustentando sus anotaciones sobre la base de la imitatio de las autoridades grecolatinas y en romance, Fernando de Herrera privilegia el aspecto de la originalidad y novedad garcilasianas, sus aportaciones a un lenguaje del arte $^{69} \mathrm{y}$ a un determinado estilo, sobre cualquier otro aspecto. José Nicolás de Azara, por su parte, al concebir el ars como condición sine qua non, adopta esencialmente el modelo del Brocense a la hora de anotar el texto (de cara a justificar su propia percepción de la literatura y revelar la erudición e imitación del toledano), pese a recurrir en numerosas ocasiones a la fuente de las Anotaciones del sevillano y a que quede manifiesto en su edición que no navega excesivamente alejado del cauce estilístico de Herrera (salvando muchas distancias). La de Azara es una edición que nos sitúa en el intersticio entre lo preceptivo y el ideario estético(-«político»).

Fernando de Herrera manifiesta en su edición de Garcilaso enorme interés en los aspectos formales de la composición poética. Considera forma y contenido elementos significativos que deben mantener una coherencia expresiva. Herrera, con Pietro Bembo, observa una «refinada actitud ante la lengua que [les] permite [...] superar las rígidas normas de la retórica clásica en una visión nueva y moderna de las características de sus respectivos vulgares y de sus medios expresivos» ${ }^{70}$.

Respecto a las cuestiones estilísticas, es curioso que la opinión de Azara no parezca diferir en demasía de las de Fernando de Herrera, al que sigue a menudo en las apreciaciones que apuntan en esta dirección, como es el caso del comentario al Soneto X. Como referimos arriba, Azara señala que «este soneto es, sin comparación, el más dulce y suave de los de G. L.» (pag. 164), en consonancia con que en él hallemos la imitación, en los dos primeros versos, de Virgilio. Herrera, por su parte, señala: «Este soneto es imitado de aquellos dulcísimos i suavíssimos versos de Virgilio...». Ambos reproducen el mismo verso, añadiendo Herrera que Garcilaso mostró en él «dulce i afetuosíssimo espíritu, porque en esta materia [...] no es inferior a Virgilio, antes ecede, considerando el encarecimiento del tiempo [...] i los contrarios de bien i de mal; pero no por esso dexa de ser menor en el modo del dezir i en la suavidad i grandeza del espíritu» ${ }^{71}$.

\footnotetext{
69 Herrera se propone en sus Anotaciones «editar la obra de un gran poeta y, al mismo tiempo, indicar la vía para el "rescate" del vulgar, es decir, reconocerle su autonomía con respecto al latín y elevarla a la categoría de lengua de arte» (Herrera, Anotaciones, pág. 43).

70 Herrera, Anotaciones, pág. 46.

71 Herrera, Anotaciones, págs. 346-347.
} 
Herrera promulga una estética que posibilite el acrecentamiento del idioma castellano, susceptible de otorgarle una mayor elevación, vigor, majestad y características similares. No obstante, esto va acompañado del interés por la musicalidad, la moderación, etc. Sin embargo, la deseable renovación del lenguaje poético que Herrera concede a la búsqueda de la sublimidad, y que vincula a la expresión de los afectos y sentimientos, así como al deseo de indagar en todo aquello que no lograron abordar los clásicos, establece una enorme distancia entre la concepción estilística del poeta sevillano y la de José Nicolás de Azara. En el caso de este, la búsqueda del término medio es mayor que en Herrera, abogando el de Barbuñales más por la claridad, naturalidad y elegancia que por todo aquello que revierta en la exaltación de lo sentimental y lo espiritual; esto puede tener cabida, pero ha de estar tamizado por la razón, máximo exponente de la teorización neoclásica. El propio estilo lingüístico con que el aragonés anota a Garcilaso es índice de tal concepción e interés. Así, podría valernos como ejemplo de la divergente conceptualización en ambos comentaristas la narración de la batalla de Gelves, notada en sendas ediciones (Égloga II, v. 1224 [1227 en Herrera]). Mientras que el sevillano se detiene, dentro de su extensa relación de lo acontecido en la batalla, en la enumeración descriptiva, Azara realiza una descripción de los hechos más breve y comedida, pese a incluir también algunos adjetivos que dan clara muestra de la heroicidad de don García de Toledo; mientras que Herrera señala que la tierra era «seca, estéril, cálida i arenosa», que «ardía el calor pestilencial con el aire de África, faltava l' agua, i casi todos perecían de sed» ${ }^{72}$, Azara indica que era el país «desierto y arenoso», y el tiempo, «estremamente caloroso», y su gente estaba «fatigada del ardor del sol y del cansancio» (pag. 70). Especialmente significativo es, en este fragmento, el modo de ambos comentadores de caracterizar la actitud de don García y narrar su fin: Herrera señala que

[...] don García animaba a todos, prometiéndoles cierta vitoria i despojos, si sufrían aquel pequeño trabajo; que se acordassen de las grandes hazañas que avían acabado en África i no quisiessen oscurecer el resplandor de su gloria afrentósamento; la mayor virtud i ecelencia de la milicia española era la tolerancia de los trabajos, i ésta perdían de todo punto, i la reputación de su nombre, si no se alentavan i, sobrepujando aquellas dificultades, no sugetavan aquella isla habitada de unos pocos i desarmados moros ${ }^{73}$.

\footnotetext{
72 Herrera, Anotaciones, pág. 876.

73 Herrera, Anotaciones, págs. 876-877.
} 
Y, más adelante, ante la emboscada organizada por los moros y la confusión generada en los sedientos soldados, don García,

[...] lleno de confusión i temor, hizo entonces oficio de fortíssimo soldado i capitán manánimo; porque peleando primero a cavallo, se apeó, i con una pica en las manos se puso delante los soldados, esortándolos a combatir con valeroso ánimo i a cobrar fuerça i osadía de la necessidad presente. I aunque vio que no lo seguían más de aquellos 60 cavalleros i algunos otros pocos, en quien pudo más la vergüença que la sed i el miedo, no desmayó; antes dio con ellos tal carga a los moros que los hizo retirar cuanto una carrera de cavallo. Pero acrecentados de nueva cavallería, rebuelven sobre ellos con tanto ímpetu que los hazen huir, i muchos, medio muertos de lassitud i cansancio, se dexavan matar. Don García quedó casi solo peleando, hasta que sin sangre i sin aliento, desamparado del espíritu, cayó sin vida entre los moros que él avía muerto, haziendo siempre famosa i memorable aquella isla con su muerte ${ }^{74}$.

Azara, sin embargo, apenas se limita a mostrar la heroicidad de don García indicando que «los animó con la voz y con el ejemplo, y con una pica en la mano peleó como valeroso soldado hasta que, muertos o dispersos todos sus españoles, oprimido de la muchedumbre, lleno de heridas, cayó muerto en la arena a los 23 años de su edad, el de 1510» (pag. 70).

Mayor evidencia de los límites de cualquier interconexión posible, o cualquier coincidencia, entre Fernando de Herrera y José Nicolás de Azara, hallamos en dos casos significativos de variantes adoptadas por uno y otro editor; dos casos en que toman decisiones críticas contrarias en pasajes que contienen, en la edición sevillana, un lexema común, oportunamente sustituido en la de 1765. El primero es el verso 4 del famoso Soneto XXIII, donde Herrera, desmarcándose de las ediciones anteriores, había introducido una lección singular sustituyendo con clara luz la tempestad serena por enciende el corazón y lo refrena. Mientras que Tamayo seguirá la versión herreriana, Azara va a recuperar la que

74 Herrera, Anotaciones, págs. 877-878. Todavía, tras continuar exponiendo la retirada de las tropas restantes, continúa Herrera en un tono legendario:

Allí pereció la flor de la gente española, aquellos que con pequeño número no solo avían resistido a grandes exércitos enemigos, pero los avían roto, destruido i muerto; los que a Orán, Bugía, Tripol, ciudades inaccesibles i poderosas en mar i tierra, fortíssimas por naturaleza i arte, avían entrado por fuerça, i despojado i destruido; aquellos valentíssimos soldados, esclarecidos con tan grandes trofeos, cuyas armas eran espantosas a toda África, rendidos a aquellos desarmados i rústicos moros, les ofrecieron el cuello para que exercitassen en ellos lo que quisiesse la ira i crueldad i soberbia del vencedor bárbaro. Murieron casi 4.000 escogidos soldados con sus capitanes i oficiales, pocos a hierro, muchos con sed i ahogados en aquellas cuevas i bocas cubiertas de la tierra i en aquellos tragaderos ascondidos (págs. 878-879). 
presentaba la fijación del Brocense. El cuarteto inicial del poema aparece en 1580 de este modo (una vez modernizadas las grafías y puntuación):

En tanto que de rosa y azucena se muestra la color en vuestro gesto, y que vuestro mirar ardiente, honesto, enciende el corazón y lo refrena;

Las variantes en el XVIII se limitan al verso 1 (En tanto que de rosa y de azucena) y al mencionado verso 4 (en ambos casos, se recupera la fijación de las ediciones anteriores a Herrera). Como se puede apreciar, la opción del sevillano origina una respuesta pasional, un movimiento, en el corazón del sujeto poético, manifiesto tanto en la aparición de enciende (con su correspondiente vinculación a lo sentimental) y refrena (que conlleva la necesidad de un movimiento previo), como en la cadencia misma del verso. Frente a esta opción, la escogida por Azara contiene un ritmo más pausado, al tiempo que sustituye el encendimiento por una calma, por una tamización del mirar ardiente y honesto (verso 3) a través de la clara luz, produciendo el efecto de serenar lo turbulento, los efectos de la pasión amorosa (la tempestad). Nos remite, a su vez, dicho verso, a dos términos cruciales en la conceptualización e ideario neoclásicos (e ilustrados): la claridad y la luz (además de la serenidad, vinculada al estado de subyugación de los sentimientos por parte del juicio, de la razón; conceptualmente asociada a la moderación).

Esta variante por sí sola resulta significativa, dada la selección de Azara entre dos posibilidades previas. Sin embargo, cobra mayor importancia si la relacionamos con una introducción novedosa, una modificación de Azara, acaecida en el verso 9 del Soneto XXXIII, dedicado A Boscán desde la Goleta. En Herrera y Tamayo, el texto era el siguiente:

Boscán, las armas y el furor de Marte, que con su propia sangre el africano suelo regando, hacen que el romano imperio reverdezca en esta parte,

han reducido a la memoria el arte

y el antiguo valor italïano,

por cuya fuerza y valerosa mano

África se aterró de parte a parte.

Aquí, donde el romano encendimiento, donde el fuego y la llama licenciosa

solo el nombre dejaron a Cartago, 
vuelve y revuelve amor mi pensamiento,

hiere y enciende el alma temerosa,

y en llanto y en ceniza me deshago.

La única variante con respecto al texto editado por Sánchez de las Brozas es la sustitución, en el verso 2, de fuerza por sangre, que Azara mantiene. En el verso 9, no obstante, donde todos los editores habían escrito encendimiento, ligado semánticamente al fuego y a la llama del siguiente, Azara, sustituyendo únicamente una letra, convierte un término emparentado con la fuerza de lo sentimental, casi instintivo, en otro directamente apoyado en la lógica, en lo racional, de tal modo que es el entendimiento ${ }^{75}$ (y no el encendimiento) el que propicia la victoria de Roma.

$\mathrm{Si}$, aun así, nos viéramos tentados a ver esta lección como fruto de un error, de un descuido, como un fruto del azar, forzado aquí para emparentar con los supuestos ideológicos del editor dieciochesco, tal vez nos haría replantearnos la cuestión la presencia de una nueva lectio singularis en este mismo poema. En el verso 12, el sintagma mi pensamiento, que en esta forma hallamos en todas las ediciones previas, se transforma al plural, mis pensamientos. Azara introduce un error: la modificación del sustantivo convierte la rima consonante (con entendimiento, precisamente) en imperfecta. Efectivamente, considerando la variante desde el punto de vista de la filología actual; sin embargo, ya hemos referido que los intereses de Azara difieren de los de la edición crítica. Al realizar la transformación mi pensamiento > mis pensamientos, a mi entender, lo que Azara está haciendo es evitar una identificación perniciosa de ese sintagma con el pensamiento como «acto del entendimiento» (Diccionario de Autoridades), que quedaría supeditado al amor, de manera contraria a la concepción que la ilustración otorga a la relación de fuerzas razón-sentimiento, donde es el juicio-razón quien debe mandar sobre las pasiones. De este modo, la presencia del plural convierte lo que podía ser interpretado como potencia en concreción «material», en resultado de la actividad del entendimiento, sin que quede resquicio posible para la ambigüedad.

Las tres lecciones mencionadas reflejan, en conjunto, la actitud intervencionista de Azara ante el texto de Garcilaso, así como su predilección por lo racional (frente a lo sentimental). Asimismo, la última de las variantes traídas a colación representa un caso de privilegio del contenido sobre la forma, de tal modo que (en esta ocasión, que no en todas) el aragonés está más interesado

75 Según se recoge en Terreros, el entendimiento es la «parte que aprehendemos en el alma, en que reside la razón, el juicio y la inteligencia, como contradistinta de la voluntad, en que reside el amor». 
en la adecuación del sentido a su propia concepción (por la relevancia de los términos en cuestión) que en la fidelidad al original garcilasiano o en el respeto mismo de la rima.

Las «correcciones» que Azara introduce en las Obras de Garcilaso muestran también la preocupación por la adecuación a un orden sintáctico más natural (o la naturalización del orden sintáctico, frente al tan característico y acentuado uso del hipérbaton en el Barroco). Podemos aducir las dos lecciones singulares del Soneto XXXI como ejemplo: en el verso 1, que las ediciones anteriores leían como Dentro en mi alma fue de mí engendrado, Azara sustituye la preposición en por de, adecuando su lectura a una normalización sintáctica, mientras que en el verso 5, mas luego dél nació quien ha estragado, se trasmuta la colocación del verbo y el complemento, siendo la lección resultante mas luego nació dél quien ha estragado.

Exponente más claro del interés de Azara en la corrección (y pureza) sintáctica castellana, así como de su interés por un uso más natural, podrían ser las variantes introducidas en los versos 272 a 274 de la Égloga II, donde corrige una estructuración de origen extranjero, de tal modo que la oración Parecía que mirando las estrellas, / clavada boca arriba en aquel suelo, / estaba a contemplar el curso dellas (en el Brocense y Tamayo; Herrera añade la preposición $a$ ante el sintagma las estrellas) se convierte en Parecía, mirando a las estrellas, / clavada boca arriba en aquel suelo, / que estaba contemplando el curso de ellas.

En algunos casos las lectiones singulares de Azara conllevan una modificación de la estructura sintáctica y del contenido semántico de los versos. Tal es el caso, por ejemplo, de la que introduce en el verso 11 del Soneto XX. En las anteriores ediciones, este verso funciona como complemento del verbo «doler», aparecido en el verso 8. Azara, sin embargo, eliminando una única letra, transformando la contracción del en artículo masculino, convierte el verso en objeto directo del verso 9 (y, a su vez, interpreta el sintagma el bien como sujeto del verbo «dejar», en lugar de como objeto directo, función que tenía en la fijación previa). El terceto resultante en la edición de Azara es este:

aunque por otra parte no me duelo, ya que el bien me dejó con su partida el grave mal que en mí está de contino.

Un caso en que encontramos cierta similitud entre la concepción estilística de Herrera y Azara es el de sus respectivas notas al verso 185 de la Égloga II, donde señala el sevillano que «esta caça entra aquí con bien liviana ocasión, i es toda imitada o antes traduzida del Sanazaro en la Prosa [8] donde podrá conferir 
el que quisiere las imitaciones; pero paréceme que para enojarse tanto Albanio $\mathrm{i}$ irse después, cuenta muchas particularidades que podrían parecer demasiadas a los que son amigos de la brevedad $i$ moderación» ${ }^{76}$. No obstante, considera Herrera que «está tratada esta traslación de la caça con grande elegancia i hermosura de versos», aprovechando la digresión para resaltar que «en éstos i otros lugares se puede hazer juizio, que ninguna cosa se puede pensar que no se declare bien en nuestra lengua i que ninguna ai tan difícil en las agenas que no l'alcance la nuestra», y para reflexionar sobre la particularidad de las distintas lenguas, lo cual le lleva a considerar «que el que imita no proponga tanto dezir lo que los otros dixeron como lo que no dixeron, si no espera que puede alcançar i ayuntar luz, números i gracia a lo que escoge por imitación; i deve el que dessea acertar dexar de tratar algo que pueda ser agradable antes que dezir alguna cosa que pueda solamente traer sospecha de ofensión» ${ }^{77}$. A Herrera responde Tamayo apuntando (tras indicar la superioridad de Garcilaso sobre Sannazaro a través de la imitación) que «no juzgará que se pone con liviana ocasión, ni que Albanio es largo con su amigo, quien supiere qué es amor; antes dirá que no sobra palabra en ella, porque, para encarecer la familiaridad y llaneza del trato con Camila, era necesario todo lo que se dijo» ${ }^{78}$ (El subrayado es mío en todos los casos). Tal vez sean comentarios como este los que lleven a Azara considerar que los de Tamayo constituyen «el mejor dechado de los despropósitos» ${ }^{79}$.

La correspondiente nota en la edición de Azara se refiere al verso 178, donde se limita a indicar: «Esta relación algo difusa de la caza es imitación o traducción de Sannazaro en la Prosa VIII» (pag. 25). Al caracterizar como difusa la relación, Azara, amigo de «la brevedad y moderación», está empleando el término en el sentido de «discurso, narración o escrito demasiadamente dilatado y superabundante de palabras, digresiones, etc.» (Diccionario de Autoridades). Sin detenerse a enjuiciar nada más que la dilación del pasaje, lo que de por sí le concede un matiz de imperfección, no se olvida el aragonés de resaltar, como Herrera, que se trata de una imitación o traducción, lo que en este caso sí carga no poca responsabilidad al poeta italiano. Frente a ambos comentaristas, Tamayo, defensor a ultranza de la obra del toledano, encarece la conveniencia y necesidad del pasaje en relación con la expresión (y efectos) de los afectos de Albanio.

El interés de Azara al cifrar cuestiones biográficas (v. 3, Canción III: «Garcilaso estuvo preso por orden de Carlos V en una de las islas del Danubio» [pag.

76 Herrera, Anotaciones, págs. 819-820.

77 Herrera, Anotaciones, pág. 820.

78 Tomás Tamayo de Vargas, Garcilaso de la Vega, natural de Toledo, príncipe de los poetas castellanos, Madrid, Luis Sánchez, 1622, 42 r. - 42 v.

79 Azara, «Prólogo del editor», [8r.]. 
142]), históricas (las numerosas referencias de la Égloga II) o mitológicas (como la mención a la transformación de Lampecia en álamo negro: v. 46, Elegía I [pag. 113]) parece ceñirse al esclarecimiento del sentido del texto, empleando para esto también una moderación que prime la lectura de los poemas mismos sobre las cuestiones de erudición que sí encontramos en Herrera (o en Sánchez de las Brozas, en relación a las referencias intertextuales con la literatura clásica y las romances), tratando, por tanto, de no excederse ni en el número ni en la extensión de sus anotaciones.

En la nota introductoria a la Canción V hace explícita Azara su intención: tras aludir a las diversas teorías acerca del destinatario del poema, advierte que «como quiera que esto sea, con lo dicho hay bastante para saber la razón por que G. L. compuso esta hermosísima canción llena de graciosas alusiones» (pag. 152).

También las definiciones y aclaraciones de vocablos o giros lingüísticos redundan en beneficio de la comprensión textual, aunque en determinadas ocasiones apunten, más bien, al señalamiento de construcciones extranjeras, como ocurre al denotar la presencia de frases «italianas» (por ejemplo, en el verso 7 de la Elegía I: «Quise pero probar si me bastase» [pag. 112]), no señaladas por los anteriores comentaristas; o usos no deseados, como la ya mencionada acuñación del confuso término «desbañar» o la nota al verso 230 de la Égloga III («Unos ejemplares dicen degollada y otros igualada. Más natural sería desangrada, porque esta señora murió de sobreparto» [pag. 104]).

Un caso claro de ilustración del significado de los versos es el de la nota situada en el tercero de la Elegía II, donde Azara cifra la dificultad (semántica) del «confusísimo terceto», que «quiere decir que el mantuano Virgilio en sus eternos versos nos conserva la memoria de que Anquíses está enterrado en Trápana» (pag. 125), información que completa remitiendo al lector al correspondiente pasaje de la Eneida, inserto también por Herrera en su comentario al verso 2 (donde refiere, además, quién es Anquises).

La nota que acompaña al verso 6 de la Canción IV está tomada casi literalmente de Herrera. Tras desvelar el sentido del término confesado, ambos señalan que «este verso humilló mucho la grandeza de esta estanza» (pag. 145). Cabe señalar que, mientras que Azara no introduce, aparte de este, ningún análisis estilístico sobre esta composición, las Anotaciones herrerianas presentan una extensa nota en que el sevillano resulta sumamente expresivo:

Sola esta canción muestra el ingenio, erudición i grandeza de espíritu de Garci Lasso; porque es tan generosa i noble i afetuosa i llena de sentimientos, i declara tan bien aquella secreta contienda de la razón $i$ el apetito, que oso dezir que ninguna de las estimadas de Italia le haze ventaja, i que pocas merecen igualdad con ella. 
Por estar toda llena de versos enteros, que son los endecasílabos, porque solo uno tiene roto en cada estança, acrecienta más gravedad i grandeza $i$ manificencia. I aunque las canciones que tienen corto solo un verso son austeras i no agradables en l' armonia, ésta no padece semejante defeto, porque va templada la gravedad con tanta dulçura $i$ belleza de lengua $i$ suavidad de números, que alcança todo lo que se puede dessear en este género ${ }^{80}$.

\section{Conclusiones}

Si, con Checa Beltrán, entendemos que «el predominio de la razón, defendido por los clasicistas, suponía un mayor énfasis en el contenido, mientras que el predominio barroco de la imaginación se correspondía con la primacía de la forma» ${ }^{81}$, no nos resultará extraño que el interés de Azara resida, precisamente, en su edición de Garcilaso, en el lenguaje mismo, puesto que este ha de ser necesariamente el vehículo para la transmisión del contenido, como cauce que haga fluir las ideas. El estilo lingüístico predilecto para Azara no será el mismo que el de Herrera, que perseguía el enaltecimiento de la propia lengua mediante la plasmación majestuosa de los afectos, sino el de la claridad, sencillez, naturalidad y elegancia. De ahí que la corrección y precisión sintáctica o semántica sean aspectos fundamentales para el ilustrado aragonés, y que se plasmen en su fijación del texto garcilasiano. No obstante, abundan también en la edición de 1765 las lecciones que repercuten en el plano fónico, bien para suavizar alguna recurrencia que pudiera considerarse excesiva, dura o artificiosa, bien para acentuarla. Indudablemente, tanto las lecciones como las notas de Azara nos muestran la búsqueda de la moderación, un estilo más racional que sentimental, pues, como sabemos, para los neoclásicos los sentimientos han de estar regidos, controlados, por el juicio; es decir, pasados por el tamiz de la razón.

Junto al carácter utilitario con que se realiza semejante edición (tanto por el planteamiento del «Prólogo» como por la fijación textual, y por la brevedad y selección de las notas, configurado todo de un modo coherente), cabe señalar la destacada preeminencia del criticismo con finalidad práctica (si bien claramente moderado y vinculado a los juicios sobre el mal gusto de los autores italianos, ejemplificando, a su vez, la importancia de una adecuada selección de modelos), en pro de una renovación (o restauración) del gusto estilístico y lingüístico, sobre la exaltación nacionalista excesiva de las virtudes garcilasianas,

\footnotetext{
80 Herrera, Anotaciones, pág. 514. El subrayado es mío.
}

81 Checa Beltrán, Razones del buen gusto, págs. 113-114. 
por más que no deje de existir, indudablemente, una configuración ideológica de carácter patriótico, tanto en las ideas concebidas en el «Prólogo» como en la justificación de la erudición de Garcilaso y su apropiada y modélica imitación de los clásicos (cuya mención prima sobre las referencias a los italianos).

No encontramos, por tanto, en la edición de Azara la explicitación de las críticas provenientes del extranjero a la literatura española ni el valor apologético que tendrán otros textos sobre poesía áurea en las décadas finales del siglo. La publicación de las Obras de Garcilaso (encuadrada dentro de un proyecto que Azara no continuaría, aunque el carácter programático aparece en la explícita intención de continuar su empresa mediante la edición de la poesía de Villegas) se nos presenta como respuesta a una necesidad netamente nacional, cuya conciencia proviene de una crítica, considerada necesaria, al estado actual de las letras y la cultura, por más que esto no deje de revertir en la configuración interesada de unos valores ideológicos, políticos y estéticos que quedan patentes en el conjunto de la obra. No obstante, como ha señalado Lopez, «ni que decir tiene que un sentimiento nacional exacerbado orientó generalmente las acciones y los discursos de esos individuos que vivieron sin saberlo la irrepetible plenitud de las Luces», refiriéndose, claro está, «a su patriótico anhelo de explorar cada vez mejor la historia nacional, y esencialmente de vindicar la cultura de los españoles» ${ }^{82}$. ¿Cómo se vierte este anhelo en la edición de Azara? En su caso, su implicación política e ideología le conducen a la recuperación/ construcción de un «clásico» del siglo XVI, digno de competir con sus modelos grecolatinos y, por supuesto, con los italianos, ofreciendo de este modo un referente para la poesía castellana, un digno representante, sí, pero sin eludir la crítica al mismo (a veces, sí, aunque no siempre, en parte justificada por la mala adopción de fuentes, italianas) y, principalmente, en aras de una regeneración del buen gusto, podríamos decir que en todas sus manifestaciones, en contraposición al ideario moral, estilístico, literario... barroco.

La edición de Azara, de este modo, se evidencia como una concreción de la actitud neoclásica y del valor de la razón como guía y destino del lenguaje, de la cultura, de la ciencia y, en definitiva, del bien común de la nación, donde no deja nunca de percibirse el quizás más distinguido y extendido sentimiento entre los neoclásicos, el sentimiento patriótico.

82 François Lopez, «La generación de 1780 y sus Parnasos», Bulletin hispanique, 109, 2 (2007), págs. 709-747, pág. 711. 